\title{
COLLABORATIVE PROFESSIONAL DEVELOPMENT FOR STATISTICS TEACHING: A CASE STUDY OF TWO MIDDLE-SCHOOL MATHEMATICS TEACHERS
}

\author{
LEANDRO DE OLIVEIRA SOUZA \\ Universidade Federal do Amazonas \\ olileo@ig.com.br \\ CELI ESPASANDIN LOPES \\ Universidade Cruzeiro do Sul \\ celilopes@uol.com.br \\ MAXINE PFANNKUCH \\ The University of Auckland \\ m.pfannkuch@auckland.ac.nz
}

\begin{abstract}
The recent introduction of statistics into the Brazilian curriculum has presented a multi-problematic situation for teacher professional development. Drawing on research in the areas of teacher development and statistical inquiry, we propose a Teacher Professional Development Cycle (TPDC) model. This paper focuses on two teachers who planned a lesson in collaboration with other teachers, implemented the lesson, and then reported on the implementation. Results indicate that the TPDC model has the potential to begin to upskill teachers with multi-dimensional development needs. TPDC provides an environment for helping teachers overcome their current beliefs and attitudes towards statistics and statistics teaching. The implications of our TPDC model for improving teachers' practice in statistics are discussed.
\end{abstract}

Keywords: Statistics education research; Teacher professional development model; Collaborative teacher development; Statistical inquiry approaches

\section{INTRODUCTION}

In Brazil, in 1998, the National Curriculum Parameters (PCN) suggested that statistics be incorporated into the mathematics middle school curriculum, and in 2002 statistics was prescribed for the high school level. The PCN are teaching guidelines that aim to guarantee the population the right to know a set of knowledge that is recognized as essential for the full exercise of citizenship in a society marked by social inequalities, rapid improvement in science and technology, and political changes of paradigms in education with regard to considering and respecting the plurality of ethnic groups, life style, beliefs and knowledge of Brazilian citizens (Campos, Carzola, \& Kataoka, 2008). Implementation of the PCN guidelines in schools faces major challenges such as (a) the initial and continued preparation of teachers; (b) didactic textbooks that have conceptual mistakes and present the content in a fragmented way; (c) the scarcity of didactic

Statistics Education Research Journal, 14(1), 112-134, http://iase-web.org/Publications.php?p=SERJ C. International Association for Statistical Education (IASE/ISI), May, 2015 
materials; (d) research results that are not yet available to schools; and (e) the lack of free software (Campos, Carzola, \& Kataoka, 2011).

We conjecture that a main obstacle to implementation of statistics into the curriculum is teacher professional development. The formalist training of Brazilian mathematics teachers hinders students' comprehension and understanding of basic concepts in statistics. Meletiou-Mavrotheris and Stylianou (2003) report that the deep and continuous effect of the formalist culture with its linear and hierarchical approaches to mathematics is prevalent in the teaching of statistics. Teachers' beliefs imported from mathematics to statistics affect and act as barriers in orienting students towards recognizing and handling uncertainty and variability. According to delMas (2004), if the conception of teaching statistics is immersed in a mathematics formalist approach, then students will have difficulties in understanding basic concepts of statistics because the reasoning is different from mathematics.

Although recent research in statistics education has produced a huge quantity of knowledge and resources (Ponte, 2011), it has not helped to change the approaches and methodologies utilized by teachers in classrooms. Part of the problem is that teachers' experience is grounded mainly in descriptive statistics and that they are challenged by recent approaches, curricula, and guidelines for statistics teaching and learning (e.g., Franklin et al., 2005; Ministry of Education, 2007). One solution to overcome such huge shifts in teaching approaches and thinking about the nature, role and purpose of statistics is for teacher educators to design and implement courses that will develop teachers' statistical thinking (Pfannkuch \& Ben-Zvi, 2011).

Currently Brazilian mathematics teachers glean their knowledge of statistics from textbooks and their own experience in university courses. To remedy the situation, the first two authors conducted a small-scale research project to improve teachers' understanding of statistics and ability to teach statistics using empirical approaches. The third author assisted with interpretation of the data and in the writing of the paper. In this paper, we report on the use of our Teacher Professional Development Cycle (TPDC) model for teacher development in statistics education and its efficacy in providing two teachers with the concepts and content needed to face the new challenges in statistics education.

\section{CURRICULAR TRENDS AND CHALLENGES TO TEACHER DEVELOPMENT IN STATISTICS}

Internationally, statistics education research (Batanero \& Diaz, 2010, Batanero, Godino, \& Cañizares, 2005; Carvalho, 2008; Gattuso, 2008; Lopes, 2003; Shi, He, \& Tao, 2009) indicates the necessity to begin teaching statistics in an inquiry-based exploratory way through simulations and projects from primary school. In addition, statistics education researchers are concerned about understanding and identifying statistical ideas that are fundamental in improving students' learning about the connections between their cultural and social worlds and statistics. Curricular documents and guidelines (e.g., Ministério da Educação, 1998, Franklin et al., 2005, National Council of Teachers of Mathematics, 2006, Ministry of Education, 2007) suggest that statistics teachers should assist middle school students to: (a) formulate questions that can be addressed with data and collect, organize, and display relevant data to answer them; (b) select and use appropriate statistical methods to analyze data; (c) develop and evaluate inferences and predictions that are based on data; and (d) understand and apply basic concepts of probability. At the heart of these guidelines is the need for a statistical inquiry approach to teaching. 
Statistics is often taught by specialized mathematics teachers who have not had specific statistics education (Burrill \& Biehler, 2011). Also, since teachers' experiences and perspectives may reflect the views they held as a student (Pierce \& Chick, 2011), teachers may not feel comfortable and confident in leading classes using data analysis and inference. Moreover, they may not be aware of the power of statistical inquiry and how it can be used to make sense of the real world (Gattuso, 2008). Consequently, they need to upgrade their knowledge through immersion in a statistical reasoning and learning environment in which a spirit of enquiry is at its heart (Pfannkuch \& Ben-Zvi, 2011). From a teaching perspective, they also need to understand the cognitive processes and mental structures that students develop during statistics instruction in order to form a rich foundation from which to interpret the effects of instructional interventions (delMas, 2004).

According to Ponte (2011), teachers need three types of knowledge. The first type is pedagogical content knowledge (Shulman, 1986), which is the amalgamated knowledge that teachers possess about how students learn content and the knowledge of design of instruction, including how to choose examples and representations, and how to guide student discussions towards accurate mathematical ideas. The second type is specialized knowledge of content, a concept suggested by Hill and Ball (2004) as a particular way for teachers to master the subject matter and that supports their activities in planning and handling classes and in assessing students' knowledge, strategies, and difficulties. The third type, professional knowledge, can be summarized as: (a) planning (includes knowledge of curriculum, classroom structure, tasks, materials, management of time, organizing students work and assessment); (b) knowledge of ways in which classroom processes of communication are handled; and (c) reflection, which is the ability to selfassess one's classroom teaching.

Reflecting about the fundamental statistical ideas described and the challenges in teaching statistical inquiry to mathematics teachers who are unfamiliar with these ideas, we believe it is necessary to understand the nature of the challenges to assist and validate teachers' actions (Makar \& Fielding-Wells, 2011). Considering that Brazilian mathematics teachers have not been prepared for the requirements that students need when they are learning statistical concepts, we developed our own TPDC model to support the many dimensions of their development needs. This model is the product of our understanding of how teachers can be supported to improve their content and conceptual knowledge and draws upon the three concepts pointed out by Ponte (2011): pedagogical content knowledge, specialized knowledge of content and professional knowledge. For our TPDC model, we also drew upon the models of Wild and Pfannkuch (1999), Makar (2008), and Makar and Fielding-Wells (2011).

Figure 1(a) shows the PPDAC (Problem, Plan, Data, Analysis, Conclusions) model of Wild and Pfannkuch (1999). Although used for statistical inquiry, this model is applicable to teacher development since it can be used to improve systems or processes. The PPDAC model concerns the way one acts and what one thinks about during the course of a statistical investigation. It is concerned with abstracting and solving a statistical problem grounded in a real problem, which is often embedded in a desire to change a system to improve something (Wild \& Pfannkuch, 1999). We view the incorporation of this model into teacher development as the first step to change the approach used in the classroom. Also the cycle is continuous: after part of a system is improved, new problems related or unrelated to the initial situation could appear, so the investigative cycle is started again. In our view, continuous improvement is essential and teachers need to undergo multiple cycles to establish expertise. 


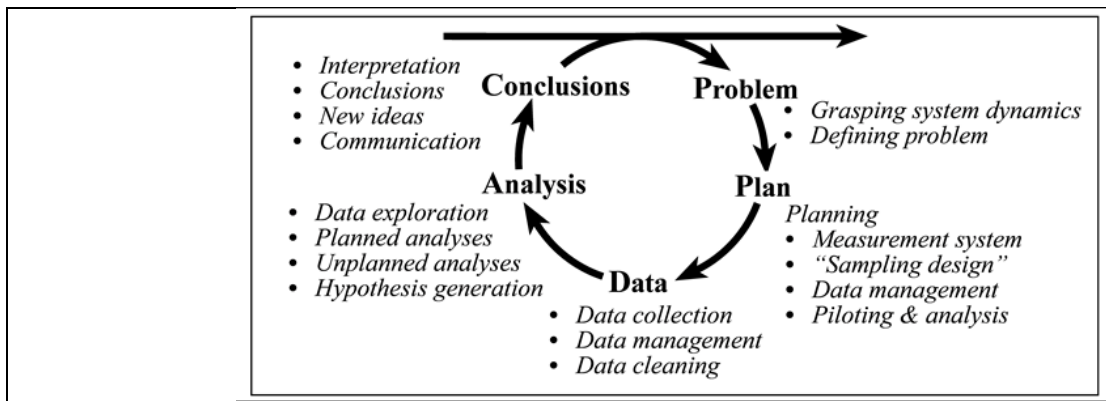

(a) PPDAC investigative cycle model (Wild \& Pfannkuch, 1999, p. 226).

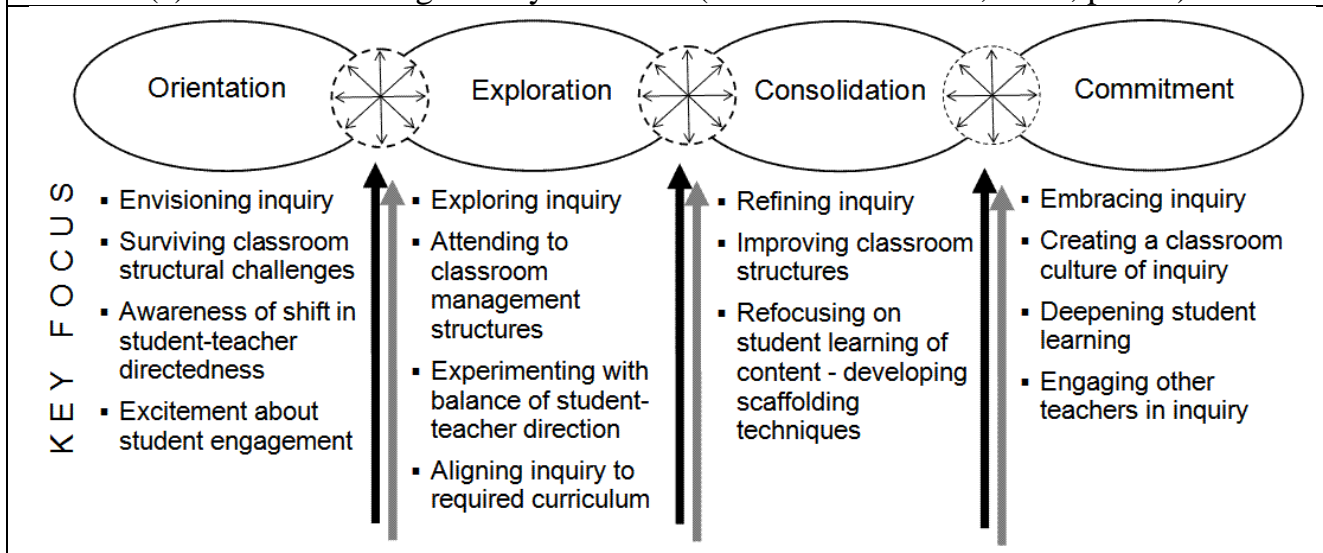

(b) Model of developing expertise in teaching statistical inquiry (Makar, 2011, p. 29). Reprinted with permission from the author.

Figure 1. Teacher development models.

Figure 1(b) shows Makar's (2011) model of developing expertise in teaching statistical inquiry. It was based on understanding the development of primary teachers' confidence, commitment, and expertise as they gained experience in teaching statistical inquiry in a supportive environment. The model of developing expertise in teaching statistical inquiry is divided into four steps: orientation cycle, exploration cycle, consolidation cycle, and commitment cycle. The orientation cycle is represented by teachers' initial experience in teaching statistical inquiry. Assisting them to begin to envision the inquiry process in a classroom setting is by far the most challenging hurdle for teacher educators (Makar, 2010). In this cycle, a paradigm rupture occurs from a traditional approach to teaching to an exploratory approach. When teachers realize that results cannot be anticipated and begin to understand the nature of inquiry, they become fascinated by the powerful applicability of the subject. During the exploration cycle, the teachers report on experiences about what statistical inquiry looks like in their classrooms, but they continue to find logistical aspects challenging such as organizing and coordinating group work, and helping students develop independence (Makar \& Fielding-Wells, 2011). As teachers increase their experience, they modify their teaching styles to begin to address these issues, and then the consolidation cycle starts.

According to Makar and Fielding-Wells (2011), the consolidation cycle is the stage in which teachers develop a "big picture" of what is involved in teaching statistical investigation and they worry less about management issues (e.g., classroom behaviors, logistical issues). Teachers in this phase feel more comfortable negotiating the balance 
between student decision-making and providing scaffolding to help their inquiry stay focused. They improve their interest in supporting student learning, such as helping students make connections between the questions being posed and the real world. To reach the commitment cycle, a process that takes at least two years, teachers include statistical inquiry as a regular part of their teaching. They also help other teachers develop and improve their teaching of inquiry.

In this paper, the research question of interest is: How does the TPDC model help two teachers with multi-dimensional development needs to start acquiring expertise in teaching statistics in new ways? The first step in answering this question was the development of our TPDC model, which is described in Section 3. The second step (covered in Section 6) involved analyzing two teachers' responses to the use of the TPDC model.

\section{TEACHER PROFESSIONAL DEVELOPMENT CYCLE MODEL}

Imbernón (2010) argues that there is a need to abandon the obsolete concept that teacher development is a scientific, didactic, and psycho-pedagogical updating of knowledge and that there is a need to replace it with the belief that teacher development should be about helping teachers to identify relevant theory and to reorganize, revise, and reconstruct their knowledge. In accord with Imbernón, our TPDC model is based on the principle that teacher development should be managed as time for reflection and innovation, instead of time for updating, with the aim of preparing teachers to create new teaching approaches and also identify and face new problems. Our TPDC model (see Figure 2) comprises five phases- orientation, exploration, application, analysis and reflection- each of which will be discussed. The design of these phases is our attempt to unify the ideas of the models described in Section 2 (Makar \& Fielding-Wells 2011; Ponte, 2011; Wild \& Pfannkuch, 1999), which we understand have the potential to enhance teachers' professional practice, and also their statistical, investigative and pedagogical knowledge. However, it should be noted that the component in the exploration phase where teachers plan their own lessons was added during the research project in response to teachers' reactions to implementing a workshop activity with their class

Most teachers do not seek educational research to support them in improving their approaches (Zeichner, 1998) because educational theory is seen as something that someone with more status and prestige can apply to their classes (Elliott, 1991). One reason for teachers' skepticism is the use of a specialized language in the academic environment that makes sense only to sub-communities of researchers. Another reason for teachers' skepticism occurs when researchers offer different teaching approaches as if they were a panacea for all their educational problems. We consider skepticism as the first obstacle to be overcome in teacher development. Therefore, before beginning the orientation phase, teachers must be listened to as a group that aspires to gain new knowledge and they should not be immersed in an environment of hierarchical relationships and subordination (Fiorentini, 2009). Teachers should be involved in identification of problems and what needs to be improved in their approaches. On the other hand, facilitators must be responsible for connecting teachers' complaints with possible solutions or alternatives. (We use the term facilitator to describe people who may be researchers, teacher educators, or professional development facilitators.) That is why we drew upon the PPDAC model (Wild \& Pfannkuch, 1999) for professional development. If facilitators go through the PPDAC model at the beginning of professional development, then teachers may understand the problems that permeate their 
practice in schools as well as gain knowledge on how to drive and plan empirical approaches for statistics lessons.

The orientation phase (Makar, 2010; Makar \& Fielding-Wells, 2011) cannot be imposed by anyone else and must have at its base the experience and needs that teachers bring to the discussion. For example, much research has pointed to the efficiency in using technologies to teach statistics (Pratt, Davies \& Connor, 2011), so facilitators may suppose that this is a good way to start a course. Although new technologies might be helpful in improving teachers' concepts, facilitators cannot assume that teachers have access to technology at school. Each school and each teacher has different problems and different needs. Therefore, the orientation phase is a negotiation between teachers who might be focused on professional issues and facilitators who might be focused on academic issues. The orientation phase has to be focused on supporting teachers to analyze and adapt their own practice, including lesson content within the spirit of statistical inquiry.

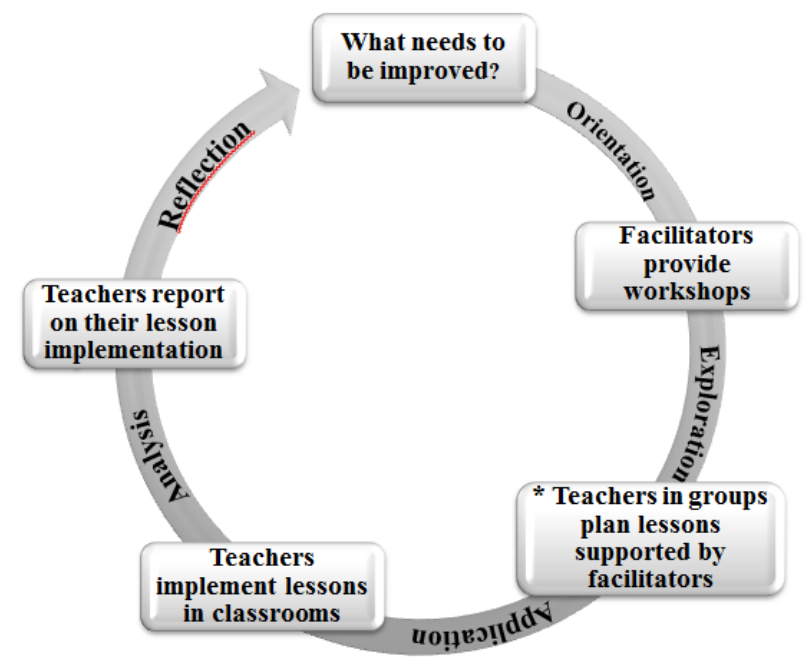

Figure 2. Teacher Professional Development Cycle model (TPDC). ( ${ }^{*}$ component added during research project)

Development of teachers cannot be regarded as training; consequently, workshops provided by facilitators must not be lectures based on solutions for generic problems (Imbernón, 2010). The contexts where teachers develop education practices are fundamentally important and facilitators must take this into account in their planning decisions. In a continuous development process, we believe it is necessary to promote teachers' autonomy if we hope that they will manage and understand their needs. Facilitators need to consider teachers' practice and knowledge (Ponte, 2011) in order to improve teachers' approaches, understanding, and educational theory and to provide them with opportunities to learn through the inquiry process and to resolve any problems associated with teaching students. It is also important for developing expertise that all involved have in mind that the interest is in what teachers do, not in what they say they do (Brown \& Coles, 2011).

The exploration phase is the time when teachers and facilitators reflect together about how to enhance students' learning through the inquiry process. Similar to the planning phase of the PPDAC model (Wild \& Pfannkuch, 1999), our model allows teachers time 
to think about and plan a statistical lesson collaboratively and also to plan how to collect data from and for their lessons. In the opinion of Garfield and Ben-Zvi (2008), the collaboration process promotes reflection on teaching when teachers verbalize and justify what is believed and practiced, which also leads teachers to question their own beliefs and practices. While teachers are trying to make connections between their planning of inquiry lessons and the curriculum, they can ask the facilitator questions. The questions might result in the facilitator reflecting on how to help teachers to link their practice knowledge with the theory. Or when teachers are predicting during lesson planning, they may resolve their own questions. The facilitator should act like a partner and be involved in this process by assisting teachers to produce better materials, assessments, and teaching techniques and by building on the diverse backgrounds and experiences of the teachers in the group.

Although one planned lesson will not change teachers' practice, the phase of application is motivated and grounded by collaboration that supports teachers in making changes that may be daunting to try on their own. According to Garfield and Ben-Zvi (2008), teachers and facilitators acting together in a group encourage and provide an environment to reflect on these changes and hence move forward, rather than abandoning efforts when they are not immediately successful. It is important that teachers are prepared to identify the reasons why a lesson did or did not work well, as well as being aware that understanding mistakes is a normal phase of the teaching process.

The phase of reporting and analysis in the TPDC model involves formative assessment, a tool that teachers do not typically use (Garfield \& Franklin, 2011). Similarly, analysis of data, drawing conclusions, and reflecting on those conclusions are also fundamental steps in the PPDAC model (Wild \& Pfannkuch, 1999). Reporting requires from teachers a self-assessment of the lesson and an analysis of their students' reasoning. When teachers are assessing students' performance to inform other teachers, they are providing feedback on how effectively students were learning the desired material, and on how they might modify instruction if necessary. In the reporting phase, both the facilitators and the other teachers can contribute with their own experiences, validating the process or assisting the teacher to reformulate concepts and the lesson. Also, when teachers are conducting the planned lesson, it is through the interaction with students that they become aware of new solutions to known problems and in this way they will develop new connections (Leikin, 2006; Leikin \& Zazkis, 2007). The major concern of facilitators (Zaslavsky, 2009) in this phase should be the need to foster teachers' reflective practice. The reflection phase of the cycle allows time to rethink, reflect, and evaluate the process of development, and is also the beginning of a new cycle.

\section{METHODOLOGY}

The methodology involved in our investigation was action research, which is described by Barbier (2004) as a process conceived to facilitate intentional changes in the practice of teachers that are decided by the researcher. Although the researcher initiates the process of action research, the researcher actually works collaboratively with those involved. Actions are the priority in this sort of research, but the researchers explore the consequences of the action with the purpose of academic research. Tripp (2005) describes four types of action research in which people can participate: obligation, co-optation, cooperation and collaboration. We chose to investigate through a process of collaboration in which people work together as co-researchers in a project where everyone has equal participation. According to Barbier (2004), action research begins in the context of a 
group in crisis, since researchers cannot initiate a problem. The problem of teacher development in statistics was provoked by statistics being newly introduced into the Brazilian curriculum. We aimed to assist all involved to become aware of the most important concepts to be taught in statistics so that they could take collective action in improving their practice.

Collaborative action research involves professionals who have in common the interest and disposition to work in groups to investigate solutions to problems that affect them. The vital role of researchers is to be part of the change process started by teachers and to lead a scientific approach focused on understanding how to improve teachers' practice (Franco, 2005). In addition, collaborative action research must allow people to work together in a way that they are free to express themselves without concern of retaliations. The group should be interested in creating a reflective community of investigation, which aims to read, think and investigate their practices (Fiorentini, 2009). Also, the group should be interested in investigating the development of a process that provides continual improvement in practice and professional development of teachers in a collaborative manner.

Sixteen teachers volunteered to participate in our research project after an invitation was sent to 80 teachers. These teachers at the time were working in schools under the government of the city of São José dos Campos, São Paulo, Brazil. Twelve of the teachers we classified as experienced ( $>5$ years teaching) whereas the other four teachers were classified as novices. To conduct our research, eleven 2.5-hour meetings were scheduled during $\mathrm{HTC}^{2}$. The data collected were video recordings of the meetings and six questionnaires spread throughout the meetings (see Figure 3).

Except for the first questionnaire, the other five questionnaires were designed after we had observed teachers in the meetings. Our aim was to obtain specific responses about aspects we had observed when they were discussing their lessons. In the first meeting, we collected data through an initial questionnaire that aimed to help us understand the professional experiences that teachers had in teaching and learning statistics, and also their experience of this subject in their undergraduate courses. Furthermore, we aimed to know what sort of teaching approaches they were currently using in their classrooms. The other five questionnaires were spread over the 10 meetings with the final questionnaire focusing on a self-assessment of the approaches utilized by teachers in their lessons, about how they were feeling in regard to teaching statistics using an inquiry process and what changes in their practice occurred as a result of being a member of the project team (see Figure 3). All the questionnaires used open-ended questions with 20 questions in the first questionnaire and approximately four questions in each of the other questionnaires.

\footnotetext{
${ }^{2}$ HTC in Portuguese means Time to Work Together. It is a period of 5 hours perweek of study. It is non-obligatory. Teachers, in groups, discuss teaching approaches, projects and anything connected with education. Frequently HTC is used by Pedagogic Coordinators to develop teachers' pedagogic concepts. Sometimes educational facilitators are hired to lead training in the subject specialty of the teachers.
} 


\begin{tabular}{|c|c|c|}
\hline & Activity in Meeting & Aim of Questionnaire given in Meeting \\
\hline \multicolumn{3}{|c|}{ What needs to be improved? } \\
\hline \multicolumn{3}{|c|}{ Statistics introduced into Brazilian curriculum. Researchers identified need to improve statistics teaching. } \\
\hline \multicolumn{3}{|c|}{ Orientation: Workshops } \\
\hline 1 & $\begin{array}{l}\text { Software for teaching statistics in an } \\
\text { environment of inquiry activities. }\end{array}$ & $\begin{array}{l}\text { Understand teachers' professional experience } \\
\text { teaching statistics and teachers' learning } \\
\text { experiences. }\end{array}$ \\
\hline 2 & $\begin{array}{l}\text { Practical activities to teach concepts of } \\
\text { variability and inference using probability. }\end{array}$ & $\begin{array}{l}\text { Identify teachers' view about the relationships } \\
\text { between teaching and learning mathematics and } \\
\text { teaching and learning statistics. }\end{array}$ \\
\hline 3 & $\begin{array}{l}\text { Scatterplot, box plot and other graphs to make } \\
\text { comparisons between two or more groups. }\end{array}$ & \\
\hline 4 & $\begin{array}{l}\text { Combinatorics and probability to make } \\
\text { predictions about events. }\end{array}$ & $\begin{array}{l}\text { Identify difficulties and problems teachers were } \\
\text { facing to modify and improve their practice. }\end{array}$ \\
\hline \multicolumn{3}{|c|}{ Exploration: Planning lessons collaboratively* } \\
\hline 5 & $\begin{array}{l}\text { Teachers organized into groups to plan a lesson, } \\
\text { the content of which was randomly selected. }\end{array}$ & \\
\hline 6 & Planning in groups. & \\
\hline 7 & Planning in groups. & $\begin{array}{l}\text { Identify teachers' perception of the research } \\
\text { project. }\end{array}$ \\
\hline 8 & Planning in groups. & $\begin{array}{l}\text { Understand what changes in the organization of } \\
\text { HTC were needed to improve the process of } \\
\text { teachers' development. }\end{array}$ \\
\hline \multicolumn{3}{|c|}{ Application: Teachers implement lesson with their class } \\
\hline \multicolumn{3}{|c|}{ Analysis: Teachers analyze their lesson implementation and report to group } \\
\hline 9 & Reporting on lesson implementation. & \\
\hline 10 & Reporting on lesson implementation. & \\
\hline 11 & Reporting and self-assessment. & $\begin{array}{l}\text { Collect data from teachers' self-assessment to } \\
\text { obtain an insight into approaches utilized in } \\
\text { lessons to identify changes in their practice. }\end{array}$ \\
\hline \multicolumn{3}{|c|}{ Reflection: What needs to be improved? } \\
\hline \multicolumn{3}{|c|}{ Teachers and researchers identify problematic areas. } \\
\hline
\end{tabular}

Figure 3. Outline of research project. (*component of TPDC model added during research project)

The meetings were divided into three phases - workshops, planning, and reporting all of which were organized and facilitated by the first two authors, the researchers. The first phase consisted of four meetings organized as workshops in which teachers had their first contact with inquiry approaches and technological tools to teach statistics. The second phase was also organized into four meetings. In this phase, we chose some content that was randomly selected by the teachers who were organized in groups. We thought that by randomly selecting the content, teachers would be challenged to plan a lesson using content with which they might not be familiar. After the content was selected, the teachers developed a lesson assisted by the researchers. Afterwards, the teachers taught the lesson to a group of students and made notes of their observations in order to report their experience to the whole group. In the third phase, the teachers reported through a presentation as to what had been successful and unsuccessful in their approaches when the lesson was applied. We finished the last phase by discussing what could be improved in their teaching of statistics and in their lesson.

In our research, we were focused on reflecting, understanding, and qualitatively analyzing how a collaborative group can develop strategies to overcome limitations in their approaches to teaching statistics content. We were also interested in analyzing how 
changes occurred in teachers' practice. After each meeting, we analyzed what had occurred using the data we had collected. This enabled us to plan the next meeting in cognizance of our purpose of assisting a practice change, and to develop the next questionnaire. Thematic analysis (Braun \& Clarke, 2006) was used for the data analysis. Thematic analysis is a "a method that works both to reflect reality and to unpick or unravel the surface of 'reality"” (p. 81) where the "theme captures something important about the data in relation to the research question, and represents some level of ... meaning within the data set” (p. 82). It is a six-stage method that starts with data familiarization, moves to collation of data into relevant themes, and finally to selecting compelling extracts that provide a rich description of the data for a group of themes within the data which relates to the question of interest for the report.

\section{DEVELOPMENT OF LESSONS AND THEIR IMPLEMENTATION}

During the workshops, we observed that teachers were interested and engaged in all the activities. We had planned that the teachers should try one of the lessons they had experienced in the workshops with their class. However, the teachers did not wish to try a lesson with their classes, as they said it was too difficult for them to introduce such an approach and their students would not be able to learn using an inquiry mode. After much consideration about this problematic situation, we determined that teachers might try something new in their classroom if they were involved in planning their own lesson. We thought that if teachers produced their own lesson they would reflect about perceived obstacles and make an effort to overcome them. We proposed this new plan to the teachers: they would work in groups to design a lesson, which followed the statistical PPDAC inquiry cycle (Wild \& Pfannkuch, 1999), where our role would be as facilitators for them and then they could trial their lesson with their class. The teachers readily agreed with this new plan. After this affirmation, we understood that just inserting teachers in programs where they work collaboratively on inquiry statistics activities was not enough to assist them to change their practice.

To start teachers on planning a lesson, we asked them to choose randomly from a box a piece of paper on which was written some statistical tools such as: box plots, dice and graphs, histograms, or column graphs and a mean. The teachers raised many questions during the planning phase such as:

- What content should have priority in the planning of the statistics classes and what approaches should we use?

- What could we do to make technological resources accessible to the students learning through inquiry statistics?

- What have other countries been doing to help their teachers overcome the lack of pedagogical approaches to teach statistics and probability?

We did not have answers to these questions. Instead, we gave suggestions to motivate the teachers to find their own answers such as seeking out research and reflecting on it. We also encouraged them to discuss experiences and ideas about the process of teaching and learning in order to try and find ways to change how they were teaching. This was done to give them autonomy to make their own decisions.

Nine teachers developed their own lesson and we observed that the process of lesson construction emerged from their teaching experiences. While these teachers were planning they were telling stories about their professional experiences and practice at the time. Sometimes they answered with critical questions, which allowed the group to explore the essence of the process of teaching and learning that occurred in the story. We conjecture that the discourse of the first story was continually modified by the stories and 
experiences told by others, and the nature of the collaborative work supported the teachers to create their own new stories. We observed that the new stories were transferred to lessons. This process was important to assist five of these teachers to move from stagnation to action inside the classroom.

Seven experienced teachers simply searched the Internet in their groups until they found a lesson design which, through their discussions, they decided met the criterion of a statistical inquiry and seemed feasible to implement. While such an approach does not address the need for teachers to learn how to plan their own lessons, these teachers chose this avenue, which we regard as an initial step away from their current reliance on the textbook. Of the four novice teachers, three implemented the lesson that they designed, while one did not. Of the twelve experienced teachers, two implemented their own lesson, seven implemented the lesson they found from the Internet, and three did not.

\section{CASE STUDY DESCRIPTIONS AND ANALYSIS}

We now describe and give our interpretation and analysis of how the planning, teaching, and reporting processes unfolded for two teachers who implemented the lesson their group designed. We also include these teachers' perceptions about teaching statistics. While these two teachers could be considered atypical of the group in that they each planned and implemented their own lesson, they are not atypical in terms of their background and perceptions of statistics. We believe that these two teachers' experiences allow some insights into the potential of the TPDC model for teachers with multidimensional needs and how the implementation and reporting phases can contribute to identification of problematic areas, engagement of teachers in the change process, and the activation of further cycles of the TPDC model.

\subsection{CASE STUDY OF TEACHER ONE: THE RECYCLING LESSON}

Teacher One background and perceptions Teacher One had graduate degrees in business management and mathematics and had taught for 11 years. She reported not feeling she had adequate knowledge to teach statistics as she had studied it only at high school and since then had never had a course on statistics or the teaching of statistics. Her experience of software was limited to Microsoft Word and Excel. When she taught statistics, which was not often, she predominantly used the textbook and focused on analyzing some graphs. She described her teaching approach as "cold and formal" and similar to the way she learned mathematics. Through participating in the research project, she hoped to increase her knowledge of statistics and to learn about approaches that could improve her teaching.

To her, statistics was about understanding and visualizing information that had been condensed into charts and graphs. In answer to a question in the second questionnaire about how statistics could help students in their life, she responded: "It could help students in their interpretation, reflection, and evaluation of information and could help them to improve their opinions about some pre-determined situations." Despite describing her teaching approach as formal, she believed that students should learn statistics through participating in projects where they could research, discover, and reason. In questionnaires three and five, she remarked that time was a problem for her to improve the quality of her statistics classes. Also her experience of professional development within HTC was that it was focused on wider educational issues rather than specific issues. She remarked: "I think that we should use this [HTC] time to discuss 
approaches to teaching content such as geometry, algebra and statistics. It would be more useful.”

Planning Teacher One planned a lesson with Teacher A, who had taught for about 15 years. Unfortunately, Teacher A, who contributed many good ideas to improve and expand their lesson, did not implement their lesson because she was in a school with major social problems and the school did not want the students' routine to be interrupted at that time.

These teachers decided to plan a lesson around environmental issues. Their initial idea was to develop and give the students a questionnaire, and then use the class data to teach them how to construct and analyze graphs. We argued that the idea was good if their aim was to teach students how to construct graphs, but if the idea was to assist students to understand how to use the statistical inquiry process they should let the students make up the questions. We explained that to develop knowledge about what could be done through statistical inquiry, the students should be involved in all phases of the inquiry process - problem, plan, data collection, analysis, and conclusion. After we intervened Teacher One mused: "Do you think that we can give the students the main issue and let them make up their questions?" She continued: "[because] I am concerned that the students may not visualize what we were doing through the graphs." We told her that in this situation if she really wants to know if the students could make up their own questions, there was no other way and that she should take the risk to see how the students reacted.

Teacher One then went back to her class and asked them for ideas about what they could investigate. Some students brought up the issue of recycling and during the discussion a student mentioned that he was interested in knowing how much money was wasted in their neighborhood, which at the time had no service for collecting recycled materials. After discussing the issue with her students she decided to share these ideas with Teacher A. After reflecting about the students' curiosity on recycling waste, the teachers decided to work on this question for their lesson plan. Teacher A reported:

We thought of a question where all the students could be involved ... We want to know how many aluminum cans are used by students' families weekly, and after that we intend to make projections to estimate how much money is wasted by the families and maybe by the neighborhood.

Once the teachers had defined the aim of their lesson, they then reflected on how they could do the lesson. Teacher One explained how she had found in her school a pin-board (see Figures 4 and 5), a resource that had been in the school for two years but had never been used.

Implementing Teacher One asked the students, ages 11 to 12, to collect some data. Each student was required to ask five people how many cans they threw away in the previous week. Working in groups of four, the students divided the pin-board into four sections and then plotted a column graph of the data they collected from their five people in the section allotted to them (Figure 4). Each bar of the column graph was a different color. To find the mean number of cans thrown away, the teacher taught the students how to obtain the mean through moving the pins so that the bars in the column graph were the same height (Figure 5). Afterwards each student compared his or her individual graph to his or her individual observed mean and median. For homework the teacher asked the students to use all the data gathered by the class to make a report that used the means to estimate how much money was going to be wasted by the people from whom they had 
collected the data in a year. The reports were also to contain their suggestions about how to reduce the money wasted.

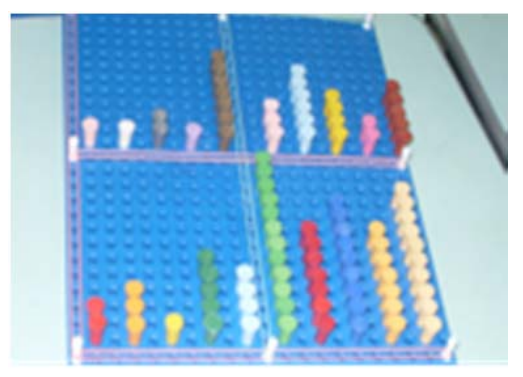

Figure 4. Student graphs on pin-board.

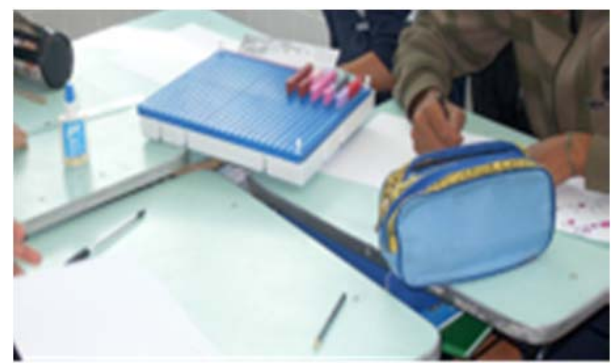

Figure 5. Students finding the mean.

Reporting In her report to the group she stated that the students already had knowledge about how to construct the graphs. She noted the following about the pinboard:

It was easy for the students to construct and reconstruct the graphs because the colors of the pins were different, so when they moved the pins to calculate the mean, it was easy to put them back. All the students participated in the lesson, including students who always have difficulties with learning mathematics. In the pictures we can see the students working, but it is not as easy as it seems. The students made a lot of noise and it was hard to manage a class of 40 students using these practical activities. But I believe that they learned how to find the mean through visualization because they showed this in their reports. In some groups, when they moved the pins to try to make the bars the same height, some pins remained. The students then realized that the mean was not an integer number, and they had no problem with calculating it because they knew the part integer of the number.

When the students compared their individual graphs the teacher reported students noticed the variation (not her language) in the observed means and explained high means by attributing it to daily alcohol drinkers.

Teacher One reflections In questionnaire four, which was given at the end of the third planning meeting (that is, the seventh meeting), Teacher One reported that she was beginning to learn statistics again, rethinking her teaching approaches and didactics, and enjoying the meetings. In the questionnaire given at the last meeting, we asked the teachers to make a brief evaluation of the project meetings. We gave some suggestions such as to talk about any activities that were significant to them, anything that changed their mind about the teaching of statistics, what needed to be improved in our development meetings and any difficulty that they had. Teacher One said:

I am re-learning about what statistics is and why it is important, also I am rethinking my practice of how to teach it. I think that if we had more meetings we could improve our practice and consequently teach this content. In the HTC meetings we discuss broad issues so that we have no opportunities to learn specific approaches, which could be used in our classes. The workshops were important but we should have more. This research modified my opinion about good approaches for teaching statistics and the importance of this subject.

Our reflections on the recycling lesson and the TPDC model for Teacher One In the recycling lesson, we noted that the teacher did not aggregate the class data together 
and instead kept each student's data separate. The teacher's statistics content observations on her teaching implementation were based on students' ability to construct plots and their development of the concept of a mean, which is not surprising given the starter activity we gave her and her beliefs about the nature of statistics. Neither she nor the whole group were able to reflect that the activity was also giving the students beginning conceptions about samples, population, variation in sample means and sample distributions. Nor did she give a wider view of the statistics content in the sense that students were starting to learn that decisions in statistics are based on reasoning from data not anecdotes and that a cycle of inquiry is pursued. Her pedagogical observations addressed managing group work with a large class and engaging all students.

Teacher One changed in several ways: from a mathematical textbook approach to statistics to planning and teaching her own lesson; from a formal transmission model of teaching to actively involving students; from textbook calculations of the mean to an empirical approach to data; and from textbook questions to contextual questions derived from student interest. In terms of her beliefs about teaching statistics she was beginning to change her opinion and practice. The reporting of her implementation allowed the researchers to identify where improvements could be made in her lesson with respect to content knowledge and pedagogy. It also reinforced the fact that engagement of students in an activity can be a powerful incentive for teachers to attempt more innovation in their practice. This case study also shows, through the discovery of the school pin-boards, that the lack of engaging teachers in more imaginative ways to teach students may be a problem rather than a lack of resources.

\subsection{CASE STUDY OF TEACHER TWO: THE AIRPLANE LESSON}

Teacher Two background and perceptions Teacher Two had a graduate degree in mathematics and it was her first year of teaching. With regard to her confidence in teaching statistics, she reported: "Unfortunately I will have to study a lot to teach statistics because in truth I hate probability, combinatorics and also statistics. In my degree we were taught basic statistical content with no concern about approaches to teaching it. I have no knowledge of how to use technology with my classes." In questionnaire two she gave some interesting comments about how she viewed statistics. For example: "Mathematics is an exact science whereas statistics is not really real but it is supported by research so it is also not a lie." She believed that students' statistical reasoning could be developed using a teaching approach where students produce and discuss their own data "in a way that they organize data and also build charts." She also mentioned time as a constraint on her ability to improve the quality of her statistics teaching and that HTC was no help improving teaching approaches as it was about reading and writing.

Planning Teacher Two, who was in her first year of teaching, and Teachers C and D, who had taught for 6 years and 15 years, respectively, chose to work on an activity using box plots. A late addition to the group was Teacher $\mathrm{E}$ whose attendance was sporadic and who had taught for 13 years. These latter three teachers did not implement the lesson, even though they professed a belief that statistics should be taught through experimentation and realistic situations. They rationalized their non-implementation of the lesson with comments about having to prioritize teaching mathematics content because, as Teacher $\mathrm{D}$ stated, her students were two years below their year level.

When planning the lesson, Teacher $\mathrm{C}$ asked: "How could we introduce this content in our class in a way which is significant to the students? Why should we do this? What will 
be our aim?" She also said: "I am worried about teaching box plots because I have never seen this graph before." Teacher D commented: "If this graph is important to the students, why do we not see it in the news?" We sought theoretical support to assist these teachers' implementation of the lesson. We presented research from Pfannkuch (2006) in which the history behind box plots is described and examples of activities and approaches are given including an analysis of students' reasoning. After explaining how box plots could be used to compare groups, we focused on practical activities and suggested to the teachers to think about a lesson where, for example, paper airplanes could be used. When we finished Teacher D said: "I like the idea; we have to define with the students some criteria. What are we going to compare? Could we compare the distance that an airplane can fly or how long it can fly? Which gender can make better airplanes, boys or girls?”

They discussed the idea for a while, when suddenly the question about the news was answered by Teacher $\mathrm{E}$ from the group. He stated:

When we are teaching statistics to the students they should be taught to understand how to make decisions without wasting time and also to comprehend how they could interpret the data to decide about some issues with only a small chance of making a mistake. A lesson about paper airplanes is a simple example, but one day they will be confronted with real situations where they will have to decide. In this case we are preparing the students to build cognitive connections that may help them to make decisions. The aim of the newspapers is just to inform, consequently we cannot see that in some graphs the aim is to infer.

Implementing Teacher Two, who implemented the airplane lesson, described her class as agitated and active with poor behavior, and where participation in activities was unusual. However, in this lesson only one of the students refused to cooperate. The students were invited to participate in a competition to build a paper airplane which could fly longer than the others (Figure 6). When the students were building their airplanes, the teacher noted that the situation was getting out of control so she asked them to launch their airplanes outside on the football pitch where they divided it into four equal parts. The football pitch divisions were drawn on two sheets of paper, one for the group of girls and the other for the group of boys. After they had launched the paper airplanes and collected data, they showed where the airplanes had landed on the sheets (see Figures 7 and 8). The difference between the girls' group and the boys' group was that the boys put all their data in a line, whereas the girls spread the data out mirroring what actually happened on the football pitch. The teacher said: "They did it well in approximately 20 minutes and were very animated." With the data in hand, the teacher the next day taught the students how to build tables, column graphs and pie graphs using the software Excel.

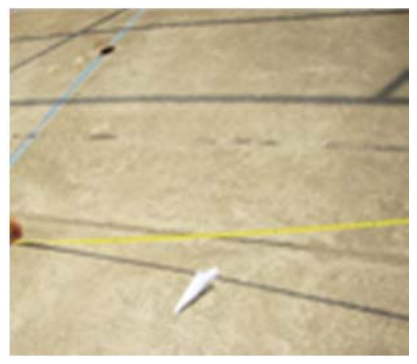

Figure 6. Measuring paper airplane flight distance.

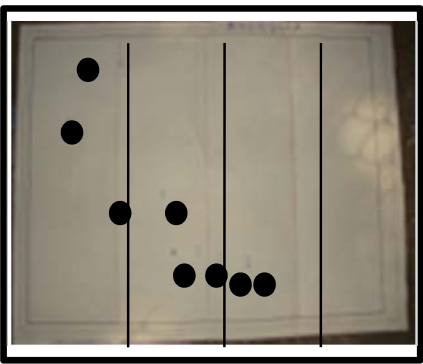

Figure 7. Girls' group results (the black points represent where the airplane landed on the football pitch).

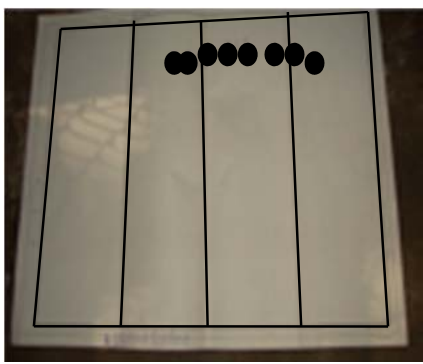

Figure 8. Boys' group results (the black points represent the distance from the launch point to the landing point). 
Reporting When Teacher Two reported back to the group of teachers, she presented the boys' and girls' airplane distance data separately as individual case values in two column graphs and two pie graphs. We asked her: "What was the aim of your lesson? "How are you going to compare the two groups?" She said she could not compare the two groups. Upon reflection, the teacher said that she now realized that her aim with the students was to compare which group, boys or girls, could make their paper airplanes more efficient according to the criterion of distance flown, and that she now understood why the column and pie graphs were not adequate. She said: "With column graphs and pie graphs in this experiment, we can just compare individual data, student by student. If our aim is to compare groups, we need another tool and I think that the box plot in this case can be effective."

Teacher Two had initially considered the box plot as a tool for displaying the data. By getting students to record their results on a piece of paper, which represented the football pitch divided into four equal parts, she was attempting to build a box plot (see Figures 7 and 8). Although we had explained how to construct box plots during the meetings, her lack of knowledge and misunderstanding about how to construct a box plot was evident. Also evident was her lack of knowledge on the inappropriateness of a pie graph to display measurement data. We noted in her discourse that her strategy was to look for tools that were familiar to her (column and pie graph) which were then used to display data without consideration of their appropriateness for the type of data that was collected. We believe that if we had more development cycles, Teacher Two could improve her knowledge of statistics.

She also reported it was not easy to teach the students using the software because they had many difficulties and they did not like to wait when she was teaching the others. Despite these reservations, she noted "some students who don't like mathematics participated very well in class. In general, the students liked the lesson; they said that they had played in a mathematics class." Such a positive response from the students led her to reorganize her teaching program to the extent that she decided to: "work with statistics every Monday through projects. Before participating in the research, I was going to teach statistics to them just in the last two months of the year. Now I realize how important it is to teach this content throughout the year.”

Teacher Two reflections In questionnaire four, which was given at the end of the third planning meeting, Teacher Two reported that she was finding it difficult to work with the other three teachers in her group, as they were quite negative. She also observed that their knowledge of statistics content was poor. Nevertheless, she was finding the meetings stimulating and thought that statistics would now be interesting to teach. However, she believed the meetings would be more useful if content knowledge and "how to apply it in our classes" was also addressed. In the final questionnaire, she said:

I observed that we needed to learn more about how to teach statistics and I was excited about my planned lesson. I have changed my mind about teaching statistics, and now I know how important it is to treat the information in statistics. I feel sorry because I had hoped to have more time to explore the software Fathom.

Our reflections on the airplane lesson and the TPDC model for Teacher Two We observed from the teacher's report on her lesson that her aim was just to show students how to construct column and pie graphs, not reason from them. In fact using pie graphs for quantitative data is incorrect. We noted that the teacher used tools that were familiar to her, which is akin to how students intuitively compare groups (Konold \& Higgins, 2003), and she realized only after actually trying such a comparison that a new tool was 
necessary. Ironically, in terms of introducing students to comparison of groups, she actually used a good teaching trajectory. She started where students were at and it was an opportunity to clarify to the students that, to interpret graphs, they also need to know what information they are looking for and whether the graphs provided that information. After such an experience, she and the students would seem to be ready to transition from an individual case value view to an aggregate view of the data (Konold, Higgins, Russell $\&$ Khalil, 2004). We observed that implementation of the lesson led the teacher to change her discourse from one that queried why box plots should be taught to one that considered that other tools were now necessary for comparison. We noted her pedagogical observations focused on two areas: (1) managing students when using computer software and (2) the engagement of students in the lesson.

Teacher Two in this instance had started to move from: hating statistics to thinking that it may be interesting to teach; not using technology to using technology with her class; and a naïve knowledge base to a recognition that she needed to upgrade her content knowledge. Similar to Teacher One, the engagement of her students in the airplane activity seemed to have incentivized Teacher Two to teach statistics now through projects. Hence a negative attitude towards statistics was seemingly replaced with a more positive attitude. Again the implementation and reporting phases of the TPDC model enabled the researchers to identify gaps in her knowledge base such as the use of pie graphs for quantitative data and the lack of clarity around her investigative question, a situation similar to Arnold's (2008) findings on 14-year-old students. Although she initially said that a constraint on using technology with her class was because there was only one computer laboratory in the school, this obstacle appeared no longer to be a factor after she implemented the lesson.

\section{CONCLUSION}

Models of teaching that are experienced by teachers throughout their academic life are resilient and may be copied particularly in the early years of the profession. Traditional approaches to teaching statistics and probability remain in our schools. The reproduction of approaches experienced in teachers' careers is shown in their practice and therefore it is important to continue in-service teacher development. New approaches have been developed by researchers and hence continuous teacher development in statistics is needed as a consequence of changes in the curriculum and changes in the way that society appropriates new information. The TPDC model seems to have the potential to provide teachers with the concepts and content to start developing their expertise to face the new challenges in statistics education.

The teachers in this research project were a small self-selected group who knew the purpose of the project and therefore were likely to be amendable to changing their teaching practice. Hence our findings are limited and cannot be generalized. Nevertheless, we believe our findings and TPDC model (Figure 2) may help to promote debate and reflections about the statistics and probability knowledge and actions needed to implement non-traditional teaching and learning approaches in classrooms where teachers have multi-dimensional problem areas to address issues such as: a mathematical approach to statistical knowledge (Meletiou-Mavrotheris \& Lee, 2002); lack of content knowledge; lack of experience in planning and teaching their own lessons (Chick \& Pierce, 2008); lack of confidence (Gattuso, 2008); lack of experience with technology (Lee \& Hollebrands, 2008); and lack of contemporary knowledge of statistics and its empirical approach (Leavy, 2010). 
The workshops oriented teachers towards a vision of how statistics could be learned (Makar, 2010). Teachers, however, recognized the gap between the vision presented by the researchers and their ability to put such a change into practice. Heeding their discontent and recognizing that teachers should be in partnership with the researchers not in a hierarchical relationship (Fiorentini, 2009; Imbernón, 2010), the original TPDC model was changed to include collaborative lesson planning. Collaborative lesson planning also addressed the need for teachers to learn how to design their own lesson, the design of which draws upon the three knowledge bases Ponte (2011) identified as necessary for teacher learning. With respect to these three knowledge bases, we observed that through designing a lesson both teachers: (a) recognized the need to improve their statistical knowledge to improve teaching approaches; (b) understood that although they needed to assess students' perceptions, they also needed to assess their own lesson reflecting carefully on their initial aim; (c) were pushed through the activity of planning a lesson to use content that they thought they knew how to lead; and (d) recognized that their approaches to statistics lessons could be improved and could be done through collaborative professional development. The setting up of a collaborative environment is paramount for facilitating change in teaching practice (Garfield \& Ben-Zvi, 2008), as is also the recognition that change is incremental, occurs over a long period of time (Makar, 2008; Makar \& Fielding-Wells, 2011), is about continuous improvement through multiple cycles (Wild \& Pfannkuch, 1999), and that it is the decision of each teacher whether, when, and how they will change.

By the end of the research project, it appeared that the two case study teachers had overcome their inability to plan their own lesson through collaboration, challenges from the researchers and appropriating the experiences of people in their group. Through implementing their own lesson, they showed that they were capable of changing their approach to teaching statistics. They found unused resources in their schools and they adapted their activities to teach content to the grades in which they were teaching.

One of the aims of our research was to find ways to assist teachers to modify their practice so that students would not only be trained only to be consumers of data, but they also could be prepared to produce their own data using an inquiry approach. What we found is that one cycle of the TPDC model seemed to help these two teachers to start to change their view about the subject. It allowed them to understand some of the problems which permeate their practice. The model facilitated discussions where connections between practice and theory are made to solve pedagogical situations. For these teachers, the engagement of their students in the lessons they designed was a pivotal moment in helping them to reflect on their current practice, a factor that was also identified by Makar and Fielding-Wells (2011) as important in teacher development. Consequently, from our observations and all the teachers' discussion, we conjecture that if we had more cycles, then more of the teachers would become engaged, especially after hearing about, for example, these two teachers' implementation of their lessons.

Teachers' lack of statistical knowledge was evident and only more cycles can move their current content knowledge beyond a focus on constructing graphs and calculating means. To engage all teachers may require a deep analysis of their reality such as community social problems within their school or their own belief system. Through the report phase and the questionnaires, the two teachers seemed to show that they had changed their view about how statistics could be better taught. They also seemed to appreciate that a good way to learn new statistical knowledge and new ways of teaching statistics is through interacting with other teachers with specialized support.

Teachers and facilitators are perceived as constant learners who should be continuously reflecting about their experiences to make sense of their work (Zaslavsky, 
2009). For example, as facilitators, the TPDC model (Figure 2) gave us an opportunity to reflect on our role in the development process and to identify ways of improving our professional practice such as modeling how to create a lesson to the teachers. The TPDC model only begins to assist teachers in developing expertise. One cycle is not enough to provide teachers with pedagogical content knowledge and the specialized knowledge of content (Ponte, 2011) necessary to change their practice. The application of the first cycle of TPDC provides an initial reflection about practices and offers a view of how teachers may act in classrooms. Teachers may learn about teaching and learning, about themselves as teachers, and about their students as learners. This was the teachers' first contact with fundamental statistical ideas of statistics: hence, the involvement of the teachers with the construction of classroom materials was not only helpful for connecting teaching aims with curriculum and assessment, but also for understanding and using the new concepts learned. As Makar (2008) demonstrated, teachers need to undergo many development cycles within three main stages: developing expertise, consolidation, and commitment.

Developing teacher expertise is a long process that needs to be supported until teachers can actively sustain their own development. Key elements in our model are:

- the creation of a supportive environment for a community of teachers;

- an orientation phase that not only takes teachers' needs into account but also exposes them to new teaching ideas;

- teachers collaboratively planning their own lessons with facilitators actively challenging them;

- teachers implementing their own lessons and reporting back to the group on their teaching experiences;

- teachers and facilitators having the opportunity to critically reflect on their practice including identifying gaps in content knowledge.

We believe that our TPDC model has the potential to assist teachers with multidimensional development needs but only further research in many different settings can attest to its effectiveness.

\section{ACKNOWLEDGMENT}

The first author would like to thank the CAPES foundation for financial support.

\section{REFERENCES}

Arnold, P. (2008). What about the P in the PPDAC cycle? An initial look at posing questions for statistical investigation. Paper presented at the 11th International Congress on Mathematical Education (ICME-11, July, 2008) Monterrey, Mexico. [Online: http://tsg.icme11.org/document/get/481]

Batanero, C., Godino, J. D., \& Cañizares, M. J. (2005). Simulation as a tool to train preservice school teachers. Proceedings of First ICMI African Regional Conference (pp. 4-6), Johannesburg, South Africa. [Online: http://www.ugr.es/ batanero/ARTICULOS/CMIRCr.pdf ].

Batanero, C., \& Diaz, C. (2010). Training teachers to teach statistics: What can we learn from research? Statistique et Enseignement, 1(1), 5-20.

[Online: http://math.univ-lyon1.fr/irem/IMG/pdf/Batanero_Diaz.pdf ].

Barbier, R. (2004). A pesquisa ação. Brasília, Brasil: Líber Livro Editora.

Braun, V., \& Clarke, V. (2006). Using thematic analysis in psychology. Qualitative Research in Psychology, 3(2), 77-101. 
Brown, L., \& Coles, A. (2011). Developing expertise: How enactivism re-frames mathematics teacher development. ZDM - The International Journal in Mathematics Education, 43(6 \& 7), 861-873.

Burrill, G., \& Biehler, R. (2011). Fundamental statistical ideas in the school curriculum and in training teachers. In C. Batanero, G. Burrill, \& C. Reading (Eds.), Teaching statistics in school mathematics - Challenges for teaching and teacher education. A Joint ICMI/IASE study (pp. 57-69). New York: Springer.

Campos, T., Cazorla, M., \& Kataoka, V. (2008). Statistical literacy in Brazil in high and middle school: An analysis of official documents. In C. Batanero, G. Burrill, C. Reading, \& A. Rossman (Eds.), Teaching statistics in school mathematics. Challenges for teaching and teacher education. Proceedings of the Joint ICMI Study 18 and 2008 IASE Round Table Conference, Monterrey, Mexico.

[Online: http://iase-web.org/documents/papers/rt2008/T1P6_Campos.pdf ].

Campos, T., Cazorla, M., \& Kataoka, V. (2011). Statistics school curricula in Brazil. In C. Batanero, G. Burrill, \& C. Reading (Eds.), Teaching statistics in school mathematics - Challenges for teaching and teacher education: A joint ICMI/IASE study (pp. 5-8). New York, NY: Springer.

Carvalho, C. (2008). Collaborative work in statistics classes: Why do it? In C. Batanero, G. Burrill, C. Reading, \& A. Rossman (Eds.), Teaching statistics in school mathematics. Challenges for teaching and teacher education. Proceedings of the Joint ICMI Study 18 and 2008 IASE Round Table Conference, Monterrey, Mexico. [Online: http://iase-web.org/documents/papers/rt2008/T1P7_Carvalho.pdf ]

Chick, H., \& Pierce, J. (2008). Teaching statistics at the primary school level: Beliefs, affordances, and pedagogical content knowledge. In C. Batanero, G. Burrill, C. Reading, \& A. Rossman (Eds.), Teaching statistics in school mathematics. Challenges for teaching and teacher education. Proceedings of the Joint ICMI Study 18 and 2008 IASE Round Table Conference, Monterrey, Mexico.

[Online: http://iase-web.org/documents/papers/rt2008/T2P3_Chick.pdf ]

delMas, R. (2004). A comparison of mathematical and statistical reasoning. In D. BenZvi, \& J. Garfield (Eds.), The challenge of developing statistical literacy, reasoning and thinking (pp. 79-95). Voorburg, The Netherlands: Kluwer Academic Publishers.

Elliott, J. (1991). Action research for educational change. Buckingham, UK: Open University Press.

Fiorentini, D. (2009). Educação matemática: Diálogos entre universidade e escola. X Encontro Gaúcho de Educação Matemática. Palestra de abertura do X Encontro Gaúcho de Educação Matemática, Ijui, Brasil.

[Online: http://www.projetos.unijui.edu.br/matematica/cd_egem/fscommand/CO/CO1.pdf ].

Franco, M. A. F. (2005). Pedagogia da pesquisa-ação. Educação e Pesquisa, 31(3), 483502.

Franklin, C., Kader G., Mewborn, D., Moreno, J., Peck, R., Perry, M., \& Scheaffer R. (2005). Guidelines for assessment and instruction in statistics education (GAISE) report: A pre-K-12 curriculum framework. Alexandria, VA: American Statistical Association.

Garfield, J., \& Ben-Zvi, D. (2008). Assessment in statistics education, developing students' statistical reasoning. New York: Springer.

Garfield, J., \& Franklin, C. (2011). Assessment of learning, for learning, and as learning in statistics education. In C. Batanero, G. Burrill, \& C. Reading (Eds.), Teaching statistics in school mathematics - Challenges for teaching and teacher education: A joint ICMI/IASE study (pp. 133-145). New York: Springer. 
Gattuso, L. (2008). Mathematics in a statistical context? In C. Batanero, G. Burrill , C. Reading, \& A. Rossman (Eds.), Teaching statistics in school mathematics. Challenges for teaching and teacher education. Proceedings of the Joint ICMI Study 18 and 2008 IASE Round Table Conference, Monterrey, Mexico. [Online: http://iase-web.org/documents/papers/rt2008/T6P1_Gattuso.pdf ]

Hill, H., \& Ball, D. (2004). Learning mathematics for teaching: Results from California's mathematics professional development institutes. Journal for Research in Mathematics Education, 35(5), 330-351.

Imbernón, F. (2010). Formação continuada de professores. Porto Alegre, Brasil: Artmed.

Konold, C., \& Higgins, T. (2003). Reasoning about data. In J. Kilpatrick, W. G. Martin, \& D. Schifter (Eds.), A research companion to principles and standards for school Mathematics (pp. 193-214). Reston, VA: National Council of Teachers of Mathematics.

Konold, C., Higgins, T., Russell, S., \& Khalil, K. (2004). Data seen through different lenses. Unpublished manuscript. [Online: http://www.srri.umass.edu/publications/konold-2004dst ]

Leavy, A. (2010). Teaching statistics at the primary level: Identifying obstacles and challenges in teacher preparation from looking at teaching. In C. Reading (Ed.), Data and context in statistics education: Towards an evidence-based society. Proceedings of the Eighth International Conference on Teaching Statistics (ICOTS-8, July, 2010), Ljubljana, Slovenia. Voorburg, The Netherlands: International Statistical Institute. [Online: http://iase-web.org/documents/papers/icots8/ICOTS8 3B3 LEAVY.pdf ].

Lee, H., \& Hollebrands, K. (2008). Preparing to teach mathematics with technology: An integrated approach to developing technological pedagogical content knowledge. Contemporary Issues in Technology and Teacher Education, 8(4), 326-341.

Leikin, R. (2006). Learning by teaching: The case of Sieve of Eratosthenes and one elementary school teacher. In R. Zazkis \& S. Campbell (Eds.), Number theory in mathematics education: Perspectives and prospects (pp. 115-140). Mahwah, NJ: Lawrence Erlbaum Associates.

Leikin, R., \& Zazkis, R. (2007). A view on teachers' opportunities to learn mathematics through teaching. Proceedings of the 31st International Group for the Psychology of Mathematics Education (pp. 122-127). Seoul, Korea: University of Seoul Press.

Lopes, C. E. (2003). O conhecimento profissional dos professores e suas relações com Estatística e Probabilidade na Educação Infantil (Doctoral dissertation, Faculdade de Educação, Universidade Estadual de Campinas, Campinas, Brasil).

Makar, K. (2008). A model of learning to teach statistical inquiry. In C. Batanero, G. Burrill, C. Reading, \& A. Rossman (Eds.), Teaching statistics in school mathematics. Challenges for teaching and teacher education. Proceedings of the Joint ICMI Study 18 and 2008 IASE Round Table Conference, Monterrey, Mexico.

[Online: http://iase-web.org/documents/papers/rt2008/T4P4_Makar.pdf ].

Makar, K. (2010). Teaching primary teachers to teach statistical inquiry: The uniqueness of initial experiences. In C. Reading (Ed.), Data and context in statistics education: Towards an evidence-based society. Proceedings of the Eighth International Conference on Teaching Statistics (ICOTS-8, July, 2010), Ljubljana, Slovenia. Voorburg, The Netherlands: International Statistical Institute.

[Online: http://iase-web.org/documents/papers/icots8/ICOTS8_3A3_MAKAR.pdf ].

Makar, K. (2011). Learning over time: Pedagogical change in teaching mathematical inquiry. In J. Clark, B. Kissane, J. Mousley, T. Spencer, \& S. Thornton (Eds.), Mathematics: Traditions and [New] Practices (Proceedings of the 34th annual conference of the Mathematics Education Research Group of Australasia and the 
Australian Association of Mathematics Teachers) (pp. 27-37). Adelaide: AAMT and MERGA.

[Online: http://www.merga.net.au/publications/counter.php?pub=pub_conf\&id=1642]

Makar, K., \& Fielding-Wells, J. (2011). Teaching teachers to teach statistical investigations. In C. Batanero, G. Burrill, \& C. Reading (Eds.), Teaching statistics in school mathematics - Challenges for teaching and teacher education: A Joint ICMI/IASE Study (pp. 347-358). New York: Springer.

Meletiou-Mavrotheris, M., \& Lee, C. (2002). Teaching students the stochastic nature of statistical concepts in an introductory statistics course. Statistics Education Research Journal, 1(2), 22-37.

[Online: http://iase-web.org/documents/SERJ/SERJ1(2).pdf ]

Meletiou-Mavrotheris, M., \& Stylianou D. (2003). On the formalist view of mathematics: Impact on statistics instruction and learning. In A. Mariotti (Ed.), Proceedings of the Third European Conference in Mathematics Education, Bellaria, Italy.

[Online: http://www.dm.unipi.it/ didattica/CERME3/proceedings/Groups/TG5/TG5_meletiou_cerme3.pdf ].

Ministério da Educação (1998). Parâmetros curriculares nacionais: Matemática (National curricular parameters: Mathematics). Brasilia, Brasil: Author.

Ministry of Education (2007). The New Zealand curriculum. Wellington, New Zealand: Learning Media Limited.

National Council of Teachers of Mathematics (2006). Curriculum focal points for prekindergarten through grade 8 mathematics: A quest for coherence. Reston, VA: Author.

Pierce, R., \& Chick, H. (2011). Teachers' beliefs about statistics education. In C. Batanero, G. Burrill, \& C. Reading (Eds.), Teaching statistics in school mathematics - Challenges for teaching and teacher education: A joint ICMI/IASE study (pp. 151162). New York: Springer.

Ponte, J. (2011). Preparing teachers to meet the challenges of statistics education. In C. Batanero, G. Burrill, \& C. Reading (Eds.), Teaching statistics in school mathematics - Challenges for teaching and teacher education: A joint ICMI/IASE study (pp. 299309). New York: Springer.

Pfannkuch, M. (2006). Comparing box plot distributions: A teacher's reasoning. Statistics Education Research Journal, 5(2), 25-45.

[Online: http://iase-web.org/documents/SERJ/SERJ5(2)_Pfannkuch.pdf ].

Pfannkuch, M., \& Ben-Zvi, D. (2011). Developing teachers' statistical thinking In C. Batanero, G. Burrill, \& C. Reading (Eds.), Teaching statistics in school mathematics - Challenges for teaching and teacher education: A joint ICMI/IASE study (pp. 323334). New York: Springer.

Pratt, D., Davies, N., \& Connor, D. (2011). The role of technology in teaching and learning statistics. In C. Batanero, G. Burrill, \& C. Reading (Eds.), Teaching statistics in school mathematics - Challenges for teaching and teacher education: A joint ICMI/IASE study (pp. 97-107). New York: Springer.

Shi, N., He, X., \& Tao, J. (2009). Understanding statistics and statistics education: A Chinese perspective. Journal of Statistics Education, 17(3), 1-8.

[Online: http://www.amstat.org/publications/jse/v17n3/shi.pdf ].

Shulman, L. S. (1986). Those who understand: Knowledge growth in teaching. American Educational Research Journal, 15(2), 4-14.

Tripp, D. (2005). Pesquisa ação uma introdução metodológica. Educação e Pesquisa 31(3), 443-466.

Wild, C. J., \& Pfannkuch, M. (1999). Statistical thinking in empirical enquiry. International Statistical Review, 67(3), 223-265. 
Zaslavsky, O. (2009). Mathematics educators' knowledge and development. In R. Even \& D. L. Ball (Eds.), The professional education and development of teachers (pp. 105-111). New York: Springer.

Zeichner, K. M. (1998). Para além da divisão entre professor-pesquisador e pesquisador acadêmico. In C. M. Geraldi, D. Fiorentini, \& E. M. Pereira (Orgs.), Cartografia do trabalho docente: Professor(a)-pesquisador(a) (pp. 207-236). Campinas, Brasil: Mercado de Letras.

LEANDRO DE OLIVEIRA SOUZA

Universidade Federal do Amazonas

Rua Nossa Senhora do Rosário, 3863 - Tiradentes

Itacoatiara, CEP: 69103-128

Amazonas - Brasil 